\title{
Optimasi Sistem Penyembunyian Data pada Audio menggunakan Sub-band Stasioner dan Manipulasi Rata-rata Statistik
}

\author{
LEDYA NOVAMIZANTI, GELAR BUDIMAN, BHISMA ADI WIBOWO
}

\author{
Program Studi S1 Teknik Telekomunikasi, Telkom University \\ Email : ledyaldn@telkomuniversity.ac.id \\ Received 11 April 2018 | Revised 8 Mei 2018 | Accepted 17 Mei 2018
}

\begin{abstract}
ABSTRAK
Kasus pelanggaran hak cipta musik atau lagu menjadi masalah dan mendapat perhatian serius oleh industri musik di Indonesia. Teknik audio watermarking merupakan salah satu solusi untuk melindungi hak cipta audio digital dari tindakan ilegal dengan cara menyembunyikan watermark berupa identitas pemilik ke dalam audio tersebut. Pada penelitian ini, audio host diubah menjadi matriks 1-dimensi untuk proses framing. Selanjutnya Stationary Wavelet Transform (SWT) digunakan untuk mendapatkan sub-band stasioner terpilih yang akan disisipkan watermark. Metode Statistical Mean Manipulation (SMM) akan menghitung rata-rata host audio dalam satu frame, dan dilakukan proses penyisipan bit. Optimasi dilakukan dengan melakukan evaluasi parameter yang menghasilkan BER paling tinggi setelah sistem diberikan serangan. Hasil dari optimasi diperoleh suatu sistem audio watermarking yang kuat dan tahan terhadap gangguan signal, dengan rata-rata BER 0.113, SNR $31 \mathrm{~dB}$, ODG -0.6, dan MOS 4.6.
\end{abstract}

Kata kunci: audio watermarking, SWT, SMM, optimasi

\begin{abstract}
The case of copyright infringement of music or song becomes a serious problem in Indonesia. Audio watermarking technique is one solution to protect the music copyright of digital audio from illegal acts by hidding the watermark in the form owner's identity into the audio. The workings of audio watermarking is to embed the watermark in the form owner's identity into the audio. In this study, the audio host is converted into a 1-dimensional matrix for the framing process. Furthermore Stationary Wavelet Transform (SWT) used to obtain stationary sub-bands selected to be inserted watermark. Statistical methods Mean Manipulation (SMM) will calculate the average host audio in one frame, and do bits insertion process. Optimization is done by evaluating the parameters that produce the highest BER after the system is given an attack. The results of the optimization obtained an audio watermarking system that is robust and resistant to signal interference, with the average BER 0.113, SNR $31 d B, O D G-0.6$, and MOS 4.6.
\end{abstract}

Keywords: audio watermarking, SWT, SMM, optimization 
Novamizanti, dkk

\section{PENDAHULUAN}

Pesatnya perkembangan dalam teknologi komputer dan internet membuat sejumlah besar media dikonversi ke bentuk digital. Ditambah pula dengan hadirnya teknologi internet yang memberikan kemudahan dalam mengakses informasi digital. Namun dari sisi pencipta karya, kedua teknologi tersebut dapat meningkatkan ancaman pembajakan dan hak cipta (Saini \& Shrivastava, 2014). Saat ini musik dengan mudah dapat dinikmati melalui data audio yang tersebar di internet maupun media lainnya. Menurut IFPI (International Federation of the Phonographic Industry), industri rekaman musik kehilangan miliaran dolar setiap tahun karena penyalinan dan distribusi file audio secara ilegal (Dutt, 2015). Salah satu solusi dari perlindungan hak cipta musik berupa data audio digital dari tindakan ilegal yaitu audio watermarking. Audio watermarking adalah proses penyembunyian informasi (watermark) ke dalam file audio sebagai sinyal host. Watermark yang tersembunyi pada file audio tersebut memiliki tantangan yang baik karena persepsi kemampuan mendengar manusia yang terbatas (Bender \& dkk, 1996) disebut human auditory system (HAS). Fakta ini menyebabkan banyak penelitian dalam pemrosesan audio menggunakan karakteristik HAS, seperti watermarking audio dan kompresi audio. Watermark disisipkan ke dalam sinyal host sedemikian rupa sehingga tidak dapat dipisahkan dari sinyal host dan tahan terhadap operasi pengolahan sinyal apa pun tanpa mengurangi performansi dari sinyal host (Husain, 2012).

Sistem audio watermarking yang dirancang oleh Chi-Man Pun dan Xiao-Chen Yuan menggunakan metode SWT dan RASE. Pada penelitian tersebut membuktikan bahwa metode SWT memiliki keunggulan pergeseran invarian yang mampu membantu lokasi segmen RASE yang bergeser akibat serangan. Ketahanan yang tinggi dapat dicapai dengan menyisipkan watermark pada koefisien aproksimasi domain SWT (Pun \& Yuan, 2013). Perancangan sistem audio watermarking yang dilakukan oleh Cui Delong dan tim nya menggunakan metode Normed Centre of Gravity (NCG) dan SWT. Hasil dari penelitian tersebut menunjukkan bahwa skema audio watermarking yang dirancang memiliki ketahanan yang baik terhadap serangan sinyal processing biasa maupun de-sinkronisasi. SWT terbukti memiliki keunggulan dalam ketahanan audio watermarking, hanya saja metode NCG digunakan hanya untuk watermark berbasis citra (Delong \& dkk, 2014). Penelitian Ching-Tang Hsieh dan Pei-Ying Tsou menggunakan metode Discrete Fourier Transform (DFT) dan Statistical Mean Manipulation (SMM) pada perancangan sistem audio watermarking. Watermark yang disisipkan pada domain ceptrum dengan menggunakan metode SMM memiliki ketahanan yang sangat baik. Hanya saja pada penelitian tersebut kapasitas frame yang dihasilkan terbatas sehingga informasi yang akan disisipkan pun menjadi terbatas (Hsieh \& Tsou, 2002). Optimasi dengan cara evaluasi parameter pada serangan yang menghasilkan performansi sistem audio watermarking paling buruk telah dilakukan oleh Budiman dkk (Budiman \& dkk, 2018). Dari penelitian tersebut diperoleh bahwa metode tersebut dapat meningkatkan kualitas dari host audio dan ekstraksi watermark yang disisipkan pada host audio yang sudah diserang.

Oleh karena itu, pada penelitian ini dilakukan perancangan sistem audio watermarking menggunakan metode SWT untuk mendapatkan sub-band stasioner terpilih yang akan disisipkan watermark. Metode SMM akan menghitung rata-rata host audio dalam satu frame, dan dilakukan proses penyisipan bit watermark. Optimasi dilakukan dengan melakukan evaluasi parameter pada lima serangan yang menghasilkan BER paling tinggi. Teknik watermarking ini diimplementasikan menggunakan lima buah data audio berformat .wav dengan genre yang berbeda, dan sebuah citra biner sebagai data watermark yang akan disisipkan ke dalam audio. Diharapkan bahwa optimasi yang diterapkan pada sistem audio watermarking akan menghasilkan suatu sistem watermarking yang kuat dan tahan terhadap serangan gangguan signal. 


\subsection{Audio watermarking}

Audio watermarking merupakan proses penyisipan data informasi kedalam suatu sinyal audio tanpa merusak atau mengubah kualitas dari audio tersebut. Watermarking dipasang pada audio untuk membuktikan kepemilikan dari audio tersebut serta perlindungan informasi yang disisipkan (Chauhan \& Risvi, 2013). Karena sinyal audio hanya berisi data satu dimensi dan sistem pendengaran manusia lebih sensitif daripada sistem visual, maka lebih sulit menyembunyikan informasi tambahan ke sinyal audio daripada ke data multimedia lainnya, tanpa menurunkan kualitas objek media (Chincholkar \& dkk, 2017).

Kriteria dari metode audio watermarking adalah sebagai berikut (Hartung \& Kutter, 1999):

a. Imperceptibility, artinya watermark yang telah tersisip sebagai informasi pemilik harus tidak terdengar dalam sinyal audio terwatermark. Sehingga harus tidak menurunkan kualitas sinyal host audio. Parameter dari imperceptibility adalah Signal to Host Ratio (SNR), Objective Different Grade (ODG) dan Subjective Different Grade (SDG).

b. Ketahanan (Robustness), artinya watermark harus mampu menangani segala macam serangan pemrosesan sinyal, seperti: low-pass filtering, kompresi MP3, penambahan echo, host dan bentuk serangan lainnya (Kiah, 2011). Parameter dari ketahanan adalah Bit Error Rate (BER).

c. Payload, menunjukkan berapa banyak bit watermark yang dapat disisipkan ke dalam host audio per satuan waktu. Parameter dari payload adalah Capacity (C).

Metode audio watermarking dapat dibagi menjadi dua domain, sebagai berikut (Rashid, 2016):

a. Domain Spasial

Pada teknik audio watermarking, domain spasial watermark langsung disisipkan pada domain waktu tanpa transformasi apapun. Teknik ini sangat mudah untuk diterapkan dan memerlukan lebih sedikit perhitungan dibandingkan dengan domain frekuensi. Namun domain spasial memiliki ketahanan yang kurang baik.

b. Domain Frekuensi

Pada teknik audio watermarking, watermark yang disisipkan dalam domain frekuensi melalui berbagai macam transformasi. Teknik ini sedikit rumit untuk diterapkan dan memerlukan lebih banyak perhitungan dibandingkan dengan domain spasial. Kelebihan dari domain frekuensi yaitu memiliki ketahanan yang jauh lebih baik.

\subsection{Stationary Wavelet Transform (SWT)}

Stationary Wavelet Transform (SWT) merupakan algoritma pada transformasi wavelet yang dirancang untuk mengatasi kelemahan pergeseran invariant pada transformasi lain. Pergeseran invarian dari SWT dapat digunakan untuk menghindari kemungkinan bahwa lokasi informasi yang diekstrak mungkin sedikit bergeser karena serangan, seperti Time Scale Modification (TSM). SWT hampir identik dengan Discrete Wavelet Transform (DWT) dalam hal struktur dekomposisi. Karena SWT tidak menggunakan down-sampling melainkan upsampling, maka sub-band akan memiliki ukuran yang sama dengan host audio input (Pun \& Yuan, 2013). Gambar 1 menunjukkan cara kerja dari sistem SWT untuk 3 level dekomposisi. Sinyal SWT dari sinyal $x$ dihitung saat melewati sinyal di beberapa filter. Sampel sinyal akan masuk melalui Low Pass Filter (LPF) dengan respon impuls $\mathrm{g}$ yang akan menghasilkan konvolusi keduanya (Al-Haj, 2011).

$$
y[n]=(x * g)[n]=\sum_{k=-\infty}^{\infty} x(k) g[n-k]
$$




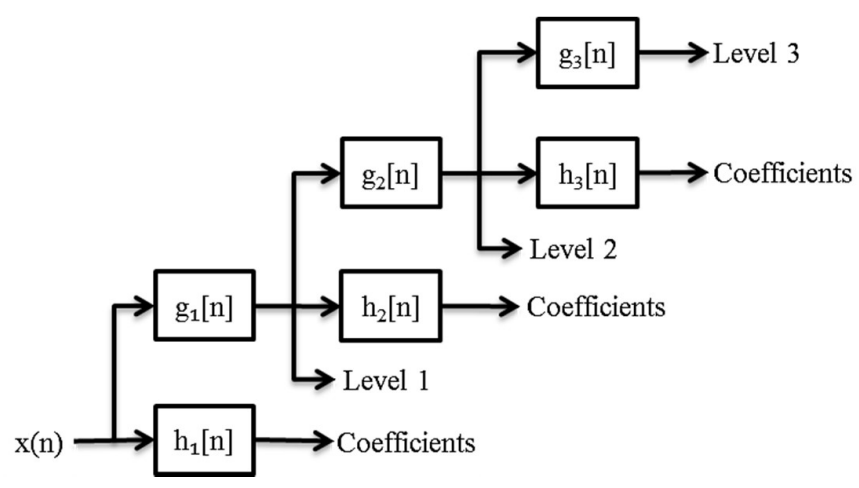

Gambar 1. Diagram Blok SWT dengan 3 Level Dekomposisi

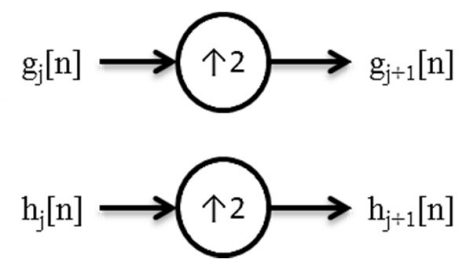

\section{Gambar 2. Up-sampling pada SWT}

Selanjutnya sinyal akan didekomposisi secara simultan dengan menggunakan High Pass Filter (HPF) h. Kemudian hasil dari kedua penyaringan tersebut akan menghasilkan koefisien detail dan koefisien aproksimasi. Karena setengah frekuensi sinyal telah dihapus, maka setengah sampel dapat dibuang sesuai dengan aturan Nyquist. Hasil filter kemudian di subsampel oleh 2 (Zeng, 2012):

$$
\begin{aligned}
& y_{\text {low }}[n]=\sum_{k=-\infty}^{\infty} x[k] g[n-k] \\
& y_{\text {high }}[n]=\sum_{k=-\infty}^{\infty} x[k] h[n-k]
\end{aligned}
$$

Setelah diperoleh koefisien SWT, maka invers SWT (ISWT) dapat dihitung untuk mengembalikan sinyal dekomposisi ke sinyal aslinya dengan menggunakan rumus berikut ini (Zeng, 2012):

$$
x[n]=\sum_{k=-\infty}^{\infty} y_{\text {high }}[k] h[n-k]+y_{\text {low }}[k] g[n-k]
$$

\subsection{Statistical Mean Manipulation (SMM)}

Statistical Mean Manipulation (SMM) merupakan suatu metode penanaman watermark pada host audio, dengan cara menghitung rata-rata (mean) host audio dalam 1 frame. SMM merupakan metode penyisipan yang menyisipkan bit header yang disinkronisasi kedalam host audio sehingga menjadi audio yang ter-watermark (Vivekananda \& dkk, 2008).

Kehandalan dari watermark bergantung pada nilai $\alpha$. Untuk mendeteksi watermark koefisien $\mu$, dihitung dan dibandingkan dengan ambang batas yang telah ditetapkan. Hal ini dikarenakan koefisiennya adalah sekitar $10^{-4}$, yang cukup kecil untuk perbandingan tersebut. Berikut formula SMM untuk teknik penyisipan (Wen \& dkk, 2009):

$$
x_{w}(n)=\left\{\begin{array}{l}
x(n)-\mu_{x}+\alpha \cdot w_{i}, \text { jika } w_{i}=1 \\
x(n)-\mu_{x}-\alpha \cdot w_{i}, \text { jika } w_{i}=0
\end{array}\right.
$$


dimana $x(n)$ adalah sinyal audio host, $\mu x$ adalah rata- rata sinyal $x(n)$ dari satu frame, $\alpha$ adalah faktor modifikasi rata-rata pada SMM, $w_{i}$ adalah watermark bit sync, dan $x_{w}(n)$ adalah audio yang telah ter-watermark.

Selain digunakan untuk proses penyisipan (embedding), SMM juga digunakan untuk proses ekstraksi watermark. Ekstraksi merupakan proses pengambilan kembali data inti atau data yang paling penting yang ada pada watermark. SMM untuk ekstraksi hampir sama dengan embedding hanya perbedaannya adalah yang dihitungnya merupakan audio yang sudah terwatermark (Hsieh \& Tsou, 2002).

Berikut formula SMM untuk teknik ekstraksi (Hsieh \& Tsou, 2002):

$$
x(n)= \begin{cases}x_{w}(n)-\mu_{x_{w}}+\alpha \cdot w_{i}, & \text { jika } w_{i}=1 \\ x_{w}(n)-\mu_{x_{w}}-\alpha . w_{i}, & \text { jika } w_{i}=0\end{cases}
$$

\subsection{Serangan pada Audio Watermarking}

Serangan pada watermarking bertujuan untuk menguji ketahanan dari teknik watermarking tersebut. Serangan diberikan pada watermarked audio sebelum melewati proses ektraksi watermark. Ketahanan audio watermarking dapat dilihat dari beberapa parameter seperti: SNR, ODG, dan BER. Jenis serangan yang digunakan pada audio watermarking adalah sebagai berikut (Harahap \& dkk, 2016):

a. Filtering, adalah proses menyaring frekuensi tertentu pada data audio digital. Frekuensi yang akan disaring ditentukan dari frekuensi cut-off. Komponen sinyal yang dibutuhkan akan dilewatkan dan yang tidak dibutuhkan akan diredam. Filtering yang digunakan, yaitu Low Pass Filter (LPF), dan Band Pass Filter (BPF). LPF merupakan jenis filter yang melewatkan sinyal frekuensi rendah dan melemahkan sinyal frekuensi tinggi, frekuensi di atas frekuensi cut-off tidak dilewatkan.

b. host atau derau, merupakan serangan dengan menambahkan sinyal gangguan (host) ke data audio digital, seperti White host, Pink host, dan Gaussian host.

c. Resampling adalah pengubahan frekuensi sampling pada sinyal asli (host audio) dengan frekuensi baru yang ditentukan, kemudian dikembalikan lagi ke frekuensi sampling awal.

d. Time Scaling Modification (TSM), adalah perubahan skala waktu pada file audio.

e. Linear Speed change, merupakan serangan dengan meningkatkan dan menurunkan kecepatan audio tanpa mengubah pitch sinyal.

f. Pitch Shifting, adalah gangguan dengan menggeser frekuensi dari watermarked audio.

g. Equalizer, adalah penyesuaian keseimbangan dengan amplitudo $=0.5$

h. Echo, adalah suara kiriman yang direfleksikan kembali ke pengirim/ asalnya dengan cukup kuat sehingga dapat dibedakan dari suara asli. Caranya dengan memberikan delay echo pada sinyal audio sebesar 0.3

i. Kompresi adalah proses untuk memperkecil ukuran data digital dengan mengubah bit rate data tersebut. Semakin kecil bit rate suatu data, maka akan semakin kecil ukurannya.

\subsection{Parameter Performansi Sistem}

Untuk mengevaluasi penelitian ini, diperlukan parameter-parameter untuk menilai performansi sistem audio watermarking. Parameter performansi sistem audio watermarking tersebut antara lain Signal to Host Ratio (SNR), Objective Different Grade (ODG), Bit Error Rate (BER), dan Mean Opinion Score (MOS). 


\subsubsection{Signal to Host Ratio(SNR)}

SNR digunakan untuk mengukur kualitas audio secara obyektif, dengan melakukan perbandingan antara audio ter-watermark $x_{w}(n)$ dengan host audio $x(n)$. Satuan yang digunakan untuk nilai SNR adalah decibel (dB). Suatu audio dinyatakan bagus kualitasnya jika SNR > $20 \mathrm{~dB}$. Persamaan yang digunakan dalam perhitungan SNR adalah (Pun \& Yuan, 2013):

$$
S N R=10 \log _{10} \frac{\sum_{i=0}^{N-1} x^{2}(n)}{\sum_{i=0}^{N-1}\left[x_{w}(n)-x(n)\right]^{2}}
$$

dimana: $N$ adalah panjang audio

\subsubsection{Bit Error Rate (BER)}

BER merupakan suatu parameter yang akan digunakan untuk penilaian obyektif. Tujuan dari BER agar host audio dan ekstraksi watermark yang disisipkan pada host audio yang sudah diserang dapat diketahui keutuhannya. BER dihitung dengan cara menghitung persentase bit yang salah dari hasil ekstraksi dengan bit keseluruhan sebelum proses penyisipan dilakukan. Persamaan BER dirumuskan sebagai berikut (Zhao \& dkk, 2015):

$$
B E R=\frac{\text { Jumlah Total Bit Error }}{\text { Jumlah Total Bit }} \times 100 \%
$$

\subsubsection{Objective Different Grade (ODG) dan Subjective Different Grade (SDG)}

Objective Different Grade (ODG) dan Subjective Different Grade(SDG) merupakan pengukuran imperceptibility berdasarkan standar ITU-R BS.1387-1. ODG dihitung melalui perhitungan kompleks pada pemrosesan sinyal audio berbasis yang bernama PEAQ (Perceptual Evaluation of Audio Quality). Pada pengukuran lain tetapi memiliki relasi yang linear, skala SDG memiliki rentang nilai dari 1 hingga 5. SDG bertujuan untuk mengetahui tingkat kualitas audio yang sudah disisipkan watermark berdasarkan indera pendengaran manusia. SDG diperoleh dari 30 responden, dengan membandingkan perubahan yang terjadi pada audio sebelum dan sesudah disisipi watermark, kemudian diberi nilai 1 hingga 5 (Budiman \& dkk, 2016). Pada Tabel 1 dapat dilihat bahwa semakin besar skala ODG dan SDG, maka semakin bagus kualitas audio yang diperoleh.

Tabel 1. Objective Different Grade (ODG)

\begin{tabular}{|c|c|c|c|}
\hline Skala ODG & Skala SDG & Kualitas & Deskripsi \\
\hline-4 & 1 & Sangat Buruk & Watermark sangat mengganggu \\
\hline-3 & 2 & Buruk & Watermark mengganggu \\
\hline-2 & 3 & Cukup & Watermark sedikit mengganggu \\
\hline-1 & 4 & Baik & Watermark terdengar, tetapi tidak mengganggu \\
\hline 0 & 5 & Sangat Baik & Watermark tidak terdengar \\
\hline
\end{tabular}

\section{METODOLOGI PENELITIAN}

Tujuan dari penelitian ini adalah mengimplementasikan suatu teknik watermarking pada data audio digital berbasis Stationary Wavelet Transform (SWT) dan Statistical Mean Manipulation (SMM), yang dapat melindungi hak cipta data digital dari tindakan ilegal. Untuk mencapai tujuan tersebut, metodologi dalam penelitian ini terdiri dari beberapa tahap yaitu: 
1. Identifikasi masalah penelitian

Pada tahap ini dilakukan identifikasi dari permasalahan dan pematangan konsep dengan studi literatur yang sesuai dengan topik penelitian. Penelitian yang telah dilakukan terdahulu dapat menjadi rujukan penting agar mendapatkan benang merah dalam melaksanakan penelitian sesuai roadmap-nya. Studi literatur yang dipelajari pada pada penelitian ini adalah sebagai berikut:
a. Teknik audio watermarking
b. Stationary Wavelet Transform (SWT)
c. Statistical Mean Manipulation (SMM)
d. Serangan pada audio watermarking
e. Performansi sistem audio watermarking

2. Pengumpulan Data

File yang akan digunakan sebagai host adalah audio mono dengan format .wav, frekuensi sampling $44100 \mathrm{~Hz}$, dan berdurasi 4-10 detik. Durasi audio bergantung pada ukuran watermark yang disisipkan. Terdapat 5 jenis file audio yang digunakan yaitu, speech (host.wav), instrument piano (piano.wav), instrument gitar (gitar.wav), instrument drum (drums.wav), dan instrument bass (bass.wav). Pesan yang dijadikan watermark adalah sebuah citra digital biner dengan resolusi 10x10 pixel.$$
\text { HE }
$$

\section{Gambar 3. Citra Watermark}

3. Perancangan Sistem

Terdapat dua buah skema rancangan yang digunakan yaitu proses penyisipan dan proses ekstraksi. Proses penyisipan bertujuan untuk menyisipkan watermark kedalam host audio, sedangkan proses ekstraksi bertujuan untuk mengambil kembali watermark yang telah disisipkan agar dapat terdeteksi. Pada sistem audio watermarking yang di rancang, pertama-tama dilakukan proses penyisipan pesan watermark ke dalam host audio. Audio yang telah diberi watermark, diuji dengan beberapa serangan, dan diekstraksi. Selanjutnya diperoleh kualitas pesan yang dihasilkan. Model sistem yang diajukan pada penelitian ini secara umum digambarkan pada diagram berikut :

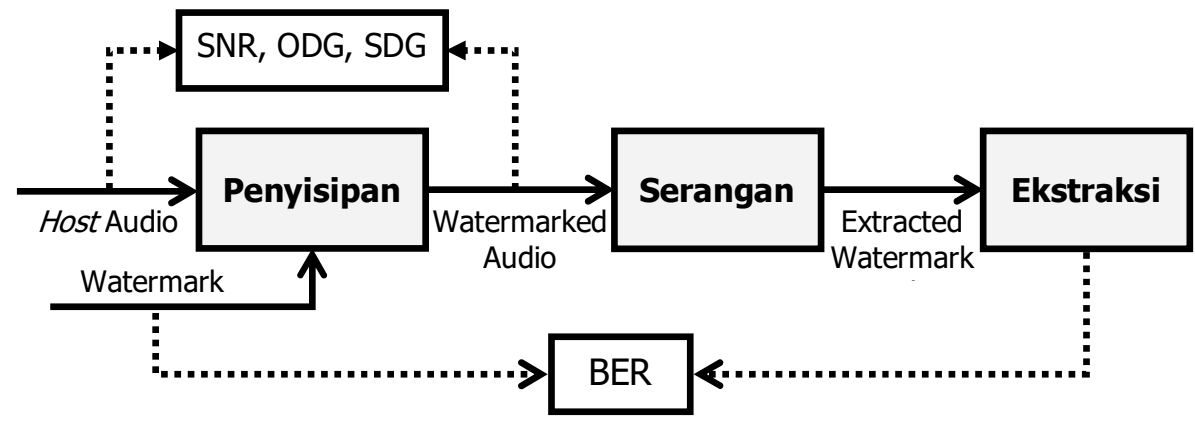

Gambar 4. Sistem Audio Watermarking Secara Umum

Pada penelitian ini, dilakukan proses penyisipan watermark berupa logo citra biner berukuran $10 \times 10$ ke dalam host audio. Gambar 5 menunjukkan diagram blok proses penyisipan. 
Langkah-langkah dalam proses penyisipan dijelaskan sebagai berikut :

Langkah 1: Baca file host audio $x(n)$, dan watermark $w(n)$. Masing-masing diubah ukurannya kedalam ukuran 1 dimensi. Ukuran watermark menjadi $1 \times 100$.

Langkah 2: Lakukan perhitungan SWT pada host audio dengan menggunakan persamaan (1). Metode SWT digunakan untuk mengubah domain waktu kedalam domain frekuensi sehingga dapat mempermudah proses penyisipan. Kemudian dihasilkan output sesuai level dekomposi dari $x(n)$ dalam bentuk beberapa sub-band. Output tersebut berupa $X_{\text {Iom }}(n)$ dan $x_{\text {high }}(n)$ yang dihitung menggunakan persamaan (2) dan (3). Selanjutnya pilih sub-band yang akan disisipkan watermark.

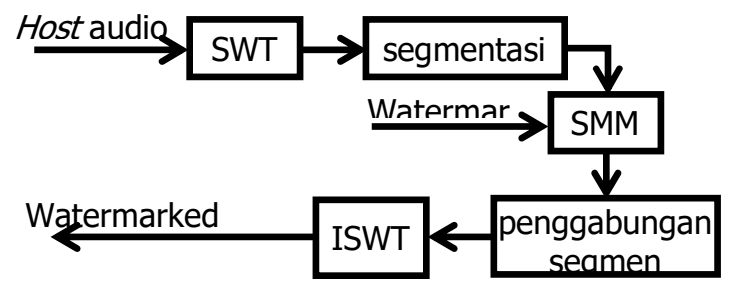

\section{Gambar 5. Diagram Blok Proses Penyisipan}

Langkah 3: Lakukan segmentasi berupa framing pada sub-band terpilih yang akan disisipkan Rumus untuk menhitung panjang frame adalah:

$$
\text { Nframe }=\frac{\text { panjang host }}{\text { panjang watermark }}
$$

Langkah 4: Hitung $\mu x$, yaitu rata- rata sinyal $x(n)$ pada tiap frame. Lakukan penyisipan bit watermark $w(n)$ ke dalam host audio dengan metode SMM pada persamaan (5), sehingga menghasilkan $x_{w}(n)$.

Langkah 5: Lakukan penggabungan seluruh frame hasil penyisipan.

Langkah 6: Lakukan perhitungan invers SWT (ISWT) untuk mengembalikan sinyal pada domain waktu. Gunakan persamaan (4) pada setiap setiap sub-band sehingga menghasilkan watermark audio $x_{w}(n)$.

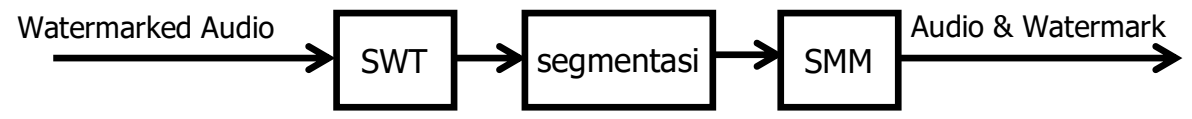

Gambar 6. Diagram Blok Proses Ekstraksi

Proses ekstraksi merupakan proses pengambilan kembali data watermark dari suatu watermarked audio. Gambar 6 menunjukan diagram blok proses ekstraksi. Langkahlangkah dalam proses ekstraksi dijelaskan sebagai berikut :

Langkah 1: Baca file watermarked audio $x_{w}(n)$.

Langkah 2: Lakukan perhitungan SWT pada watermarked audio dengan menggunakan persamaan (1-3), sehingga menghasilkan $\widehat{x_{w}}(n)$.

Langkah 3: Lakukan segmentasi pada sub-band yang mengandung watermark dengan ukuran Nframe sampel/segmen.

Langkah 4: Hitung $\mu_{x_{w}}$ yaitu rata- rata sinyal audio yang telah ter-watermark, $\widehat{x_{w}}(n)$. Lakukan proses ekstraksi pada $\widehat{x_{w}}(n)$ dengan menggunakan SMM pada segmen host audio. Persamaan (7) digunakan untuk mendapatkan kembali host audio. Bit watermark yang telah disisipkan pada proses 
Optimasi Sistem Penyembunyian Data Pada Audio menggunakan Sub-band Stasioner dan Manipulasi Rata-rata Statistik

penyisipan diperoleh dengan persamaan 10 (Hsieh \& Tsou, 2002).

$$
\widehat{w}_{i}(n)=\left\{\begin{array}{l}
0, \text { jika } \mu_{x_{w}}<0 \\
1, \text { jika } \mu_{x_{w}} \geq 0
\end{array}\right.
$$

Setelah proses ekstraksi selesai, dapat dihitung nilai BER antara watermark sebelum ekstraksi $w(n)$ dengan watermark setelah ekstraksi $\widehat{w}(n)$.

4. Pengujian dan analisis performansi sistem

Pengujian parameter yang dilakukan antara lain : pengaruh level dekomposisi $(\mathrm{N})$, jumlah frame (N Frame), nilai threshold, dan nilai $\alpha$ terhadap performansi sistem audio watermarking, yaitu: ODG, SNR, BER, dan C. Pengujian selanjutnya dilakukan uji serangan untuk mengetahui tingkat ketahanan sistem watermarking terhadap tindak perusakan yang mungkin terjadi pada implementasinya. Serangan yang digunakan pada penelitian ini yaitu LPF, BPF, host, resampling, time scale modification, linier speed change, pitch shifting, echo, dan kompresi. Pengujian secara subjektif dilakukan berupa survei SDG menggunakan 30 orang koresponden, dengan membandingkan audio asli dengan watermarked audio untuk mendukung analisis dari kualitas sistem audio watermarking.

5. Optimasi Sistem

Selanjutnya dilakukan optimasi terhadap host audio yang memiliki kerusakan terparah ketika diserang. Optimasi ini dilakukan dengan cara mengevaluasi parameter yang digunakan hingga mendapatkan ODG, SNR, dan BER yang paling optimal. Setelah diperoleh parameter optimal, maka parameter tersebut diuji terhadap seluruh serangan dan seluruh audio host untuk mendapatkan performansi sistem. Sehingga diperoleh parameter terbaik yang memiliki ODG, SNR, dan BER paling optimal.

\section{HASIL DAN DISKUSI}

\subsection{Pengujian Parameter Sistem}

1. Uji Parameter Level Dekomposisi (N)

Nilai N menunjukkan banyakannya dekomposisi yang dilakukan oleh SWT. Semakin banyak level dekomposisi artinya semakin banyak juga pembagian frekuensi yang dilakukan. Pada pengujian ini, digunakan sampel audio host.wav dengan nilai $\mathrm{N}$ dari 1 sampai 5, parameter Nframe $=2048$, thr $=0,1$, dan alfa $=0,001$.

Tabel 2. Pengaruh Nilai N Terhadap ODG, SNR, BER, dan C

\begin{tabular}{|c|c|c|c|c|}
\hline $\mathbf{N}$ & ODG & SNR & BER & C \\
\hline 1 & 0,0899 & 30,3183 & 0 & 21,53 \\
\hline 2 & 0,1167 & 30,5951 & 0,49 & 21,53 \\
\hline 3 & 0,1365 & 30,7576 & 0,25 & 21,53 \\
\hline 4 & 0,1446 & 30,8532 & 0,51 & 21,53 \\
\hline 5 & 0,1498 & 30,9101 & 0,41 & 21,53 \\
\hline
\end{tabular}

Hasil pada Tabel 2 menunjukkan bahwa level dekomposisi (N) berpengaruh terhadap ODG, SNR, dan BER. Namun tidak berpengaruh terhadap Capacity (C). Pada level dekomposisi, $\mathrm{N}=1$ memberikan hasil BER yang diharapkan, yaitu 0 . Artinya hasil ekstraksi dari watermarked audio dapat utuh kembali, sama dengan kondisi sebelum watermark disisipkan pada host audio. Pada Gambar 7 menunjukkan citra hasil ekstraksi pada beberapa nilai $\mathrm{N}$, dari 1 hingga 4 . Sehingga parameter $\mathrm{N}=1$ digunakan untuk pengujian parameter berikutnya. 


\section{䡒}

(a)

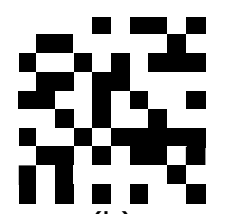

(b)

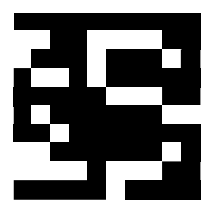

(c)

Gambar 7. Pengaruh Nilai $N$ terhadap Citra Hasil Ekstraksi (a) $N=1$, (b) $N=2$, (c) $N=3$

2. Uji Parameter Panjang Frame (Nframe)

Pada pengujian ini, digunakan sampel audio host.wav dengan menggunakan parameter yang diperoleh dari pengujian sebelumnya yaitu, $\mathrm{N}=1$, thr=0,1, dan alfa=0,001.

Tabel 3. Pengaruh Nframe terhadap ODG, SNR, BER, dan C

\begin{tabular}{|c|c|c|c|c|}
\hline Nframe & ODG & SNR & BER & C \\
\hline 128 & $-2,9701$ & 3,0108 & 0 & 544,53 \\
\hline 256 & $-3,4071$ & 9,3998 & 0 & 172,27 \\
\hline 512 & $-1,4374$ & 16,2873 & 0 & 86,13 \\
\hline 1024 & $-0,2595$ & 24,8645 & 0 & 43,07 \\
\hline 2048 & 0,0899 & 30,3183 & 0 & 21,53 \\
\hline 4096 & 0,1603 & 36,3947 & 0 & 10,77 \\
\hline 8192 & 0,1646 & 37,5896 & 0 & 5,38 \\
\hline
\end{tabular}

Hasil pada Tabel 3 menunjukkan bahwa nilai Nframe berpengaruh terhadap nilai ODG, SNR, dan C. Namun tidak berpengaruh terhadap BER. Semakin besar Nframe maka semakin baik nilai ODG dan SNR yang dihasilkan, namun banyak bit watermark yang dapat disisipkan ke dalam host audio semakin berkurang. Sehingga parameter Nframe $=2048$ digunakan untuk pengujian parameter berikutnya, karena menghasilkan nilai SNR dan ODG yang paling baik.

\section{Uji Parameter Threshold}

Nilai threshold akan menentukan nilai daya yang dapat dipilih sebagai lokasi penyisipan. Pada pengujian ini, digunakan sampel audio host.wav dengan menggunakan parameter yang diperoleh dari pengujian sebelumnya yaitu, $N=1$, Nframe $=2048$, dan alfa=0,001. Hasil pada Tabel 4 menunjukkan bahwa parameter threshold tidak mempengaruhi performansi sistem.

Tabel 4. Pengaruh Threshold terhadap ODG, SNR, BER, dan C

\begin{tabular}{|c|c|c|c|c|}
\hline thr & ODG & SNR & BER & C \\
\hline 0,001 & 0,0899 & 30,3183 & 0 & 21,53 \\
\hline 0,01 & 0,0899 & 30,3183 & 0 & 21,53 \\
\hline 0,1 & 0,0899 & 30,3183 & 0 & 21,53 \\
\hline 1 & 0,0899 & 30,3183 & 0 & 21,53 \\
\hline
\end{tabular}

4. Uji Parameter Alfa

Parameter alfa merupakan faktor penggeser rata-rata yang akan berpengaruh terhadap metode pengisipan SMM. Pada pengujian ini, digunakan sampel audio host.wav dengan menggunakan parameter yang diperoleh dari pengujian sebelumnya yaitu, $N=1$, Nframe $=2048$, dan thr=0,1. 
Optimasi Sistem Penyembunyian Data Pada Audio menggunakan Sub-band Stasioner dan Manipulasi Rata-rata Statistik

Tabel 5. Pengaruh Alfa terhadap ODG, SNR, BER, dan C

\begin{tabular}{|c|c|c|c|c|}
\hline alfa & ODG & SNR & BER & C \\
\hline 0,001 & 0,0961 & 30,3141 & 0 & 21,53 \\
\hline 0,002 & 0,0299 & 29,0987 & 0 & 21,53 \\
\hline 0,003 & $-0,0279$ & 27,7074 & 0 & 21,53 \\
\hline 0.004 & $-0,1117$ & 26,3369 & 0 & 21,53 \\
\hline 0.005 & $-0,1801$ & 23,8983 & 0 & 21,53 \\
\hline
\end{tabular}

Pada Tabel 5 menunjukkan bahwa nilai alfa berpengaruh terhadap ODG dan SNR. Namun tidak berpengaruh terhadap BER dan kapasitas bit watermark. Semakin besar nilai alfa yang digunakan maka semakin buruk nilai ODG dan SNR yang dihasilkan. Sehingga parameter alfa $=0,001$ digunakan sebagai parameter sistem, karena menghasilkan nilai ODG dan SNR yang paling baik.

\subsection{Pengujian Ketahanan Sistem Watermarking}

Untuk mengetahui ketahanan suatu watermark, maka watermark perlu diuji oleh berbagai macam serangan. Parameter yang digunakan dalam pengujian ini diperoleh dari hasil pengujian dan analisis sebelumnya, yaitu: level dekomposisi $(\mathrm{N})=1$, Nframe $=2048$, threshold $=0,1$, dan alfa $=0,001$.

Tabel 6. Pengaruh Serangan terhadap BER

\begin{tabular}{|c|c|c|c|c|c|c|}
\hline \multirow{2}{*}{ Serangan } & \multirow{2}{*}{ Kriteria } & \multicolumn{5}{|c|}{ BER } \\
\hline & & host & piano & gitar & drum & bass \\
\hline \multirow[t]{3}{*}{ LPF } & $3 \mathrm{k}$ & 0 & 0 & 0 & 0 & 0 \\
\hline & $6 \mathrm{k}$ & 0 & 0 & 0 & 0 & 0 \\
\hline & $9 \mathrm{k}$ & 0 & 0 & 0 & 0 & 0 \\
\hline \multirow[t]{3}{*}{ BPF } & $100-6 \mathrm{k}$ & 0,56 & 0,48 & 0,58 & 0,38 & 0,58 \\
\hline & $50-6 k$ & 0,56 & 0,43 & 0,61 & 0,32 & 0,58 \\
\hline & $25-6 k$ & 0,56 & 0,42 & 0,53 & 0,3 & 0,6 \\
\hline \multirow[t]{3}{*}{ Host } & $0 \mathrm{~dB}$ & 0,48 & 0,43 & 0,5 & 0,57 & 0,59 \\
\hline & $10 \mathrm{~dB}$ & 0,48 & 0,43 & 0,51 & 0,52 & 0,47 \\
\hline & $20 \mathrm{~dB}$ & 0,38 & 0,57 & 0,49 & 0,41 & 0,42 \\
\hline \multirow[t]{3}{*}{ Resampling } & $22.05 \mathrm{k}$ & 0 & 0 & 0 & 0 & 0 \\
\hline & $11.025 \mathrm{k}$ & 0 & 0 & 0 & 0 & 0 \\
\hline & $16 \mathrm{k}$ & 0 & 0 & 0 & 0 & 0 \\
\hline \multirow[t]{3}{*}{ TSM } & $1 \%$ & 0,3 & 0,32 & 0,27 & 0,15 & 0,37 \\
\hline & $2 \%$ & 0,2 & 0,39 & 0,4 & 0,16 & 0,49 \\
\hline & $4 \%$ & 0,27 & 0,43 & 0,44 & 0,14 & 0,38 \\
\hline \multirow{3}{*}{$\begin{array}{l}\text { Linear Speed } \\
\text { Change }\end{array}$} & $1 \%$ & 0 & 0 & 0 & 0 & 0 \\
\hline & $5 \%$ & 0 & 0 & 0 & 0 & 0 \\
\hline & $10 \%$ & 0 & 0 & 0 & 0 & 0 \\
\hline \multirow[t]{3}{*}{ Pitch Shifting } & $1 \%$ & 0,32 & 0,46 & 0,4 & 0,19 & 0,5 \\
\hline & $2 \%$ & 0,29 & 0,44 & 0,43 & 0,16 & 0,43 \\
\hline & $4 \%$ & 0,3 & 0,39 & 0,41 & 0,19 & 0,45 \\
\hline Equalizer & & 0,48 & 0,41 & 0,48 & 0,19 & 0,55 \\
\hline Echo & & 0,3 & 0,33 & 0,41 & 0,25 & 0,52 \\
\hline \multirow{4}{*}{$\begin{array}{c}\text { Kompresi } \\
\text { MP3 }\end{array}$} & $32 \mathrm{k}$ & 0,04 & 0,03 & 0,13 & 0,02 & 0,46 \\
\hline & $64 \mathrm{k}$ & 0 & 0 & 0,07 & 0,02 & 0,34 \\
\hline & $128 \mathrm{k}$ & 0 & 0 & 0,01 & 0 & 0,14 \\
\hline & $192 \mathrm{k}$ & 0 & 0 & 0 & 0 & 0 \\
\hline \multicolumn{2}{|c|}{ Rata-rata } & \multicolumn{5}{|c|}{0,206} \\
\hline
\end{tabular}


Pada pengujian ini, digunakan 5 jenis audio yang berbeda diantaranya, host.wav, piano.wav, gitar.wav, drums.wav, dan bass.wav. Hasil pada Tabel 6 menunjukkan bahwa watermark yang disisipkan pada 5 host memiliki ketahanan terhadap beberapa serangan. Sistem audio watermarking yang dirancang tahan terhadap serangan LPF, resampling, linear speed change, dan kompresi MP3 pada 192k karena BER yang dihasilkan pada uji serangan tersebut bernilai 0 untuk semua jenis audio. Dari hasil uji serangan tersebut, diambil 3 sampel parameter yang memiliki BER tinggi untuk dilakukan optimasi, yaitu :

1. Parameter 1 : serangan TSM (2\%) pada audio piano.wav yang menunjukan hasil BER bernilai 0,39.

2. Parameter 2 : serangan pitch shifting (4\%) pada gitar.wav yang menunjukan hasil BER bernilai 0,41 .

3. Parameter 3 : serangan kompresi MP3 (32k) pada bass.wav yang menunjukan hasil BER bernilai 0,46 .

Ketiga parameter tersebut dievaluasi kembali dengan melakukan pengujian pencarian paramater terbaik yang memiliki kinerja sistem yang optimal.

\subsection{Optimasi Parameter Sistem}

Optimasi dilakukan dengan cara mengganti parameter N, Nframe, threshold, dan alfa secara bergantian pada sistem audio watermarking yang diserang oleh serangan TSM (2\%), pitch shifting (4\%), dan kompresi MP3 (32k), diperoleh hasil sebagai berikut:

Tabel 7. Pengaruh Parameter Optimasi terhadap Kinerja Sistem

\begin{tabular}{|c|c|c|c|c|c|c|c|c|c|}
\hline Parameter & Audio & $\mathbf{N}$ & Nframe & thr & alfa & ODG & SNR & BER & C \\
\hline 1 & piano & 1 & 4096 & 0,1 & 0,009 & $-2,1473$ & 31,5408 & 0 & 10,77 \\
\hline 2 & gitar & 1 & 8192 & 0,1 & 0,0045 & $-0,0059$ & 27,7557 & 0 & 5,38 \\
\hline 3 & bass & 1 & 8192 & 0,1 & 0,004 & $-0,0027$ & 28,8872 & 0,19 & 5,38 \\
\hline
\end{tabular}

Ketiga parameter optimal yang diperoleh pada pengujian sebelumnya digunakan untuk semua jenis audio dan serangan, sehingga menghasilkan output berupa nilai BER. Parameter terbaik dipilih melalui nilai rata-rata BER yang paling baik. Tabel 8 menunjukkan hasil ketahanan watermark terhadap serangan menggunakan 3 parameter.

Tabel 8. Perbandingan Rata-rata BER dari Parameter Sebelum dan Sesudah Optimasi pada 5 File Audio

\begin{tabular}{|c|c|c|c|}
\hline BER Sebelum & \multicolumn{3}{|c|}{ BER Setelah Optimasi } \\
\cline { 2 - 4 } Optimasi & Parameter 1 & Parameter 2 & Parameter 3 \\
\hline 0,218 & 0,118 & 0,113 & 0,115 \\
\hline
\end{tabular}

Hasil pada Tabel 8 menunjukkan bahwa setelah optimasi, parameter 2 memberikan hasil BER yang paling baik, karena menghasilkan rata-rata BER paling kecil.

Tabel 9. Nilai SNR dan ODG untuk Parameter 2

\begin{tabular}{|c|c|c|c|}
\hline \multirow{2}{*}{ Audio } & \multicolumn{3}{|c|}{ Parameter 2 (BER=0.113) } \\
\cline { 2 - 4 } & ODG & SDG & SNR \\
\hline host & 0,106 & 4,5 & 26,672 \\
\hline piano & $-0,437$ & 4,5 & 37,817 \\
\hline gitar & $-0,002$ & 4,7 & 28,689 \\
\hline drums & $-2,171$ & 4,6 & 31,152 \\
\hline bass & $-0,308$ & 4,5 & 32,12 \\
\hline Rata-rata & $\mathbf{- 0 , 5 6 2}$ & $\mathbf{4 , 6}$ & $\mathbf{3 1 , 2 9 0}$ \\
\hline
\end{tabular}


Kemudian pada Tabel 9 diperoleh bahwa parameter 2 menghasilkan nilai ODG dan SNR sangat baik untuk semua jenis audio, kecuali audio drums. Sedangkan hasil SDG menyatakan bahwa semua audio yang dihasilkan memiliki kualitas yang baik. Hal tersebut dikarenakan keterbatasan sistem persepsi manusia dalam hal pendengaran. Secara keseluruhan, parameter 2 memberikan performansi sistem yang baik, karena nilai SNR > 20dB dan nilai ODG pada kriteria watermark terdengar, tetapi tidak mengganggu audio.

\subsection{Pengaruh Optimasi Terhadap BER}

Gambar 8 menunjukkan bahwa setelah optimasi, sistem audio watermarking tahan terhadap serangan LPF, Resampling, TSM, Linier speed change, pitch shifting, equalizer, echo, dan kompresi MP3. Rata-rata BER setelah optimasi mengalami peningkatan sebesar $45 \%$, yaitu dari 0.206 menjadi 0.113 . Sistem audio watermarking tahan terhadap serangan filter LPF, namun belum tahan terhadap serangan BPF, baik sebelum maupun setelah dioptimasi. Hal tersebut dikarenakan BPF merupakan gabungan antara filter highpass dan lowpass, dimana high pass filter adalah kebalikan dari low pass filter. High pass filter adalah jenis filter yang mampu melewatkan frekuensi tinggi, dan meredam frekuensi rendah.

Pada serangan host, optimasi pada sistem audio watermarking memberikan peningkatan performansi BER sebesar $15 \%$, dari rata-rata BER 0,48 menjadi 0,44. Namun hasil yang diperoleh masih belum memberikan audio host dan pesan watermark hasil ekstraksi yang utuh saat sebelum disisipkan kedalam audio host. Sistem melakukan reduksi host dengan filter frekuensi high pass, dimana sistem ini rentan terhadap filter high pass.

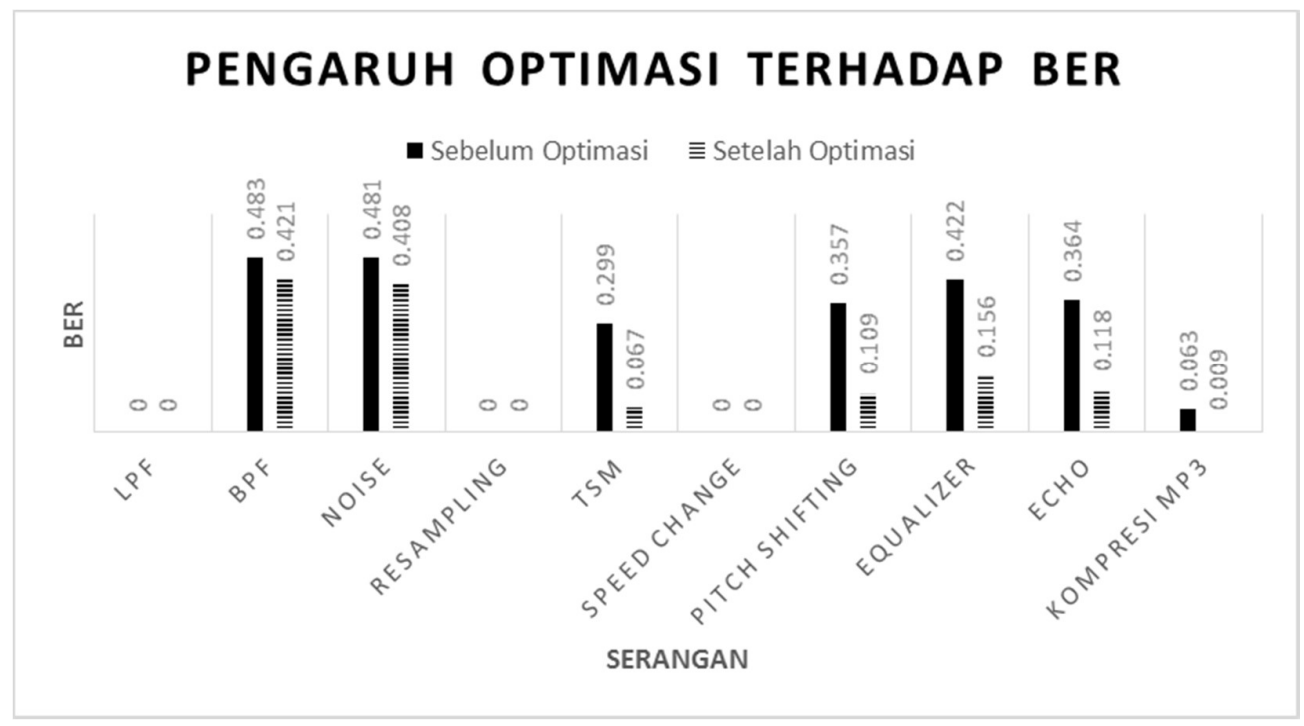

Gambar 8. Pengaruh Optimasi Terhadap BER

\section{KESIMPULAN}

Pada penelitian ini telah dirancang suatu sistem watermarking pada file audio wav dengan menggunakan Stationary Wavelet Transform dan Statistical Mean Manipulation, dengan ketahanan yang baik terhadap beberapa serangan, yaitu LPF, resampling, TSM, linear speed change, pitch shifting, equalizer, echo, dan kompresi mp3. Namun sistem audio watermarking belum tahan terhadap serangan BPF, dan host. Setelah optimasi, diperoleh rata-rata $\mathrm{BER}=0,113, \mathrm{ODG}=-0,6, \mathrm{SNR}=31,290$, dan $\mathrm{SDG}=4.6$. Terjadi peningkatan BER sebesar $45 \%$ dibandingkan sebelum optimasi. Berdasarkan kriteria imperceptibility, disimpulkan bahwa watermark terdengar, namun tidak mengganggu audio. Hal ini membuktikan bahwa setelah 
optimasi, sistem audio watermarking semakin tahan terhadap serangan. Parameter optimal dari sistem audio watermarking, yaitu level dekomposisi $\mathrm{N}=1$, panjang frame Nframe $=8192$, threshold thr $=0,1$, dan alfa $=0.0045$. Level dekomposisi $(N)$ berpengaruh terhadap ODG, SNR, dan BER, namun tidak berpengaruh terhadap Capacity (C). Semakin besar level dekomposisi artinya semakin banyak juga pembagian frekuensi yang dilakukan. Untuk SWT, level dekomposisi terbaik pada $\mathrm{N}=1$. Semakin besar Nframe maka semakin baik nilai ODG dan SNR yang dihasilkan, namun jumlah bit watermark yang dapat disisipkan ke dalam host audio semakin berkurang. Oleh karena itu, setelah optimasi hanya diperoleh Capacity=5,38 bit/detik. Langkah selanjutnya perlu dilakukan penyempurnaan dari sistem yang telah dirancang, agar watermark yang dapat disisipkan ke dalam host audio mempunyai kapasitas yang lebih besar. Parameter threshold tidak mempengaruhi performansi sistem. Sedangkan nilai alfa berpengaruh terhadap ODG dan SNR, namun tidak berpengaruh terhadap BER dan kapasitas bit watermark. Semakin besar nilai alfa yang digunakan maka semakin buruk nilai ODG dan SNR yang dihasilkan. Namun performansi sistem menurun ketika alfa $<0.0045$.

\section{DAFTAR RUJUKAN}

Saini, L. K., \& Shrivastava, V. (2014). A Survey of Digital Watermarking Techniques and its Applications. International Journal of Computer Science Trends and Technology (IJCST), 2(3), $70-73$.

Dutt, S. (2015). A Survey of Digital Audio watermarking Techniques. International Journal of Computer Science and Information Technologies (IJCSIT), 6(3), 3067 - 3072.

Bender, W., Gruhl, D., Morimoto, N., \& Lu, A. (1996). Techniques for data hiding. IBM Systems Journal, 35(3.4), $313-336$.

Husain, F. (2012). A Survey of digital Watermarking Techniques for Multimedia Data. MIT International Journal of Electronics and Communication Engineering, 2(1), 37 - 43.

Pun, C. M., \& Yuan, X. C. (2013). Robust Segments Detector for De-Synchronization Resilient Audio watermarking. IEEE Transactions On Audio Speech and Languange Proccessing, $2412-2424$

Delong, C., Qirui, L., Guilan, Y., \& Jianbin, X. (2014). Conten-Based Audio watermarking Based To Resist De-Synchronization Attacks. International Conference on Information and Network Security.

Hsieh, C., \& Tsou, P. (2002). Blind Cepstrum Domain Audio watermarking Based on Time Energy Features. International Conference on Digital Signal Processing, (pp. 705 -708).

Budiman, G., Suksmono, A. B. \& Danudirdjo, D. (2018). FFT-Based Audio Watermarking in Adaptive Subband with Spread Spectrum Framework. Journal of Telecommunication and Computer Engineering (JTEC), in press. 
Chauhan, S. P. S., \& Rizvi, S. A. M. (2013). A survey: Digital audio watermarking Techniques and Applications. 4th International Conference on Computer and Communication Technology (ICCCT), (pp. 185-192).

Chincholkar, Y. D., Ganorkar, S.R., \& Kude, S.P. (2017). A Survey: Digital Audio Watermark Designed Method. International Journal of Advanced Research in Computer and Communication Engineering, 6(6), 288 - 292.

Hartung, F., \& Kutter, M. (1999). Multimedia Watermarking Techniques. Proceeding IEEE, 877), (pp. 1079 - 1107).

Kiah, M. L. M., Zaidan, B. B., Zaidan, A. A. Ahmed A. M., \& Al-Bakri, S. H. (2011). A Review of audio Based Steganography and Digital Watermarking. International Journal of the Physical Sciences, 6(16), 3837 - 3850.

Rashid, A. (2016). Digital Watermarking Applications and Techniques: A Brief Review. International Journal of Computer Applications Technology and Research, 5(3), 147 150.

Al-haj, A., Mohammad, A., \& Bata, L. (2011). DWT - Based Audio watermarking. The International Arab Journal of Information Technology, 8(3), 326 - 333.

Zeng, W. (2012), A Novel Audio watermarking Algorithm based on Chrip Signal and Discrete Wavelet Transform. 8th International Conference on Wireless Communications, Networking and Mobile Computing (WiCOM), (pp. 0 - 3).

Vivekananda, B. K., Sengupta, I., \&, Das, A. (2008). Audio watermarking Based On Mean Quantization In Cepstrum Domain. 16th International Conference on Advanced Computing and Communications (ADCOM), (pp. 73 - 77).

Wen, X., Ding, X., Li, J., Gao, L., \& Sun, H. (2009). An Audio Watermarking Algorithm Based on Fast Fourier Transform. International Conference on Information Management, Innovation Management and Industrial Engineering, (pp. 363 - 366).

Harahap, H., Budiman, G., Novamizanti, L. (2016). Implementasi Teknik Watermarking menggunakan FFT dan Spread Spectrum Watermark pada Data Audio Digital. Jurnal Elkomika, 4(1), 98 - 109.

Zhao, M., Pan, J., \& Chen, S. (2015). Optimal SNR of Audio watermarking by Wavelet and Compact PSO Methods. Journal of Information Hiding and Multimedia Signal Processing, 6(5), $833-846$.

Budiman, G., Suksmono, A. B., \& Danudirdjo, D. (2016). A Modified Multicarrier Modulation Binary Data Embedding in Audio File. International Journal on Electrical Engineering and Informatics, 8(4), 762 - 774. 